\title{
Sistem Deteksi Cacat Kayu dengan Metode Deteksi Tepi SUSAN dan Ekstraksi Ciri Statistik
}

\author{
PUTU DEBBY WANANDA, LEDYA NOVAMIZANTI, RATRI DWI ATMAJA
}

Program Studi S1 Teknik Telekomunikasi Telkom University

Email : debbywananda92@gmail.com

Received 25 Oktober 2017 | Revised 5 Desember 2017 | Accepted 28 Januari 2018

\begin{abstract}
ABSTRAK
Kayu menjadi suatu bahan dasar untuk menghasilkan berbagai macam jenis produk olahan kayu. Untuk menghasilkan produk olahan kayu dengan kualitas tinggi, dengan ketahanan produk yang kuat, dan umur dari produk olahan kayu tersebut dapat bertahan lama maka diperlukan bahan dasar kayu yang berkualitas dalam artian tanpa cacat sebagai bahan dasarnya. Pada penelitian ini telah dirancang sebuah sistem pendeteksian kayu untuk mengklasifikasikan kayu normal (tanpa cacat) dan kayu rusak dengan metode deteksi tepi SUSAN dan ekstraksi ciri statistik orde kedua, dengan tingkat akurasi sebesar 90,67\% dan waktu komputasi 2,5 detik. Sehingga mengurangi adanya human error dan efisiensi waktu dalam pensortiran. Parameter nilai threshold $(t)=0,1$ pada metode deteksi tepi SUSAN, dan ciri angular second moment (ASM), correlation, variance, dan inverse different moment (IDM) pada metode ekstraksi ciri statistik orde kedua, memberikan hasil optimal dalam sistem ini.
\end{abstract}

Kata kunci: cacat kayu, deteksi tepi SUSAN, ekstraksi ciri statistik

\begin{abstract}
Wood becomes a basic material to produce various types of wood processing products. To produce high quality processed wood products, with robust product durability, and long life of the processed wood products can last a long time it takes quality wood base material in the sense without flaw as the basic material. In this research, we have designed a wood detection system to classify normal wood (without defects) and damaged wood with SUSAN edge detection method and second order statistic extraction with accuracy of $90.67 \%$ and computation time 2.5 seconds. Thus reducing human error and time efficiency in sorting. The threshold value parameter $(t)=0.1$ on the SUSAN edge detection method, and angular second moment (ASM), correlation, variance, and inverse different moment (IDM) characteristics in second order statistical feature extraction methods, gives optimal results in this system.
\end{abstract}

Keywords: wood defect, SUSAN edge detector, statistical feature extraction 


\section{PENDAHULUAN}

Hasil survei Badan Pusat Statistik (BPS, 2017) mencatat bahwa sepanjang 2015, volume ekspor kayu lapis Indonesia seberat 2,47 juta ton, naik 5,4 persen dibanding tahun sebelumnya. Nilai ekspor kayu lapis mencapai US\$2,37 miliar, naik tipis dari tahun sebelumnya US\$ 2,23 miliar. Hal ini mendorong industri kayu olahan untuk tetap dapat bersaing dalam memproduksi produk - produk unggulan kayu olahan. Demi tercapainya olahan kayu yang berkualitas tinggi dan tahan dalam waktu lama, industri olahan kayu ini harus memilih kayu yang berkualitas untuk bahan baku. Kayu dengan kualitas rendah dan cacat akan berpengaruh terhadap kualitas, kekuatan dan ketahanan kayu tersebut. Disinilah peran teknologi dan informasi untuk mengurangi terjadinya kesalahan manusia dalam pemilihan kayu yang akan diolah. Peran teknologi komunikasi dan informasi di sini adalah untuk membuat software yang dapat dipakai dalam membedakan dan/atau mendeteksi kayu yang cacat atau kayu yang berkualitas tinggi. Dengan teknologi ini pekerjaan lebih efisien dan mengurangi terjadi human error. Cacat kayu perlu diperhatikan karena sangat berpengaruh terhadap kekuatan dan umur dari produk kayu olahan. Cacat kayu dapat terjadi karena alam seperti cacat mata kayu, borok karena luka, maupun retak akibat proses pengangkutan, pengeringan, dan finishing.

Penelitian sebelumnya merancang sistem pensortiran otomatis untuk mendeteksi cacat pada kayu dengan berbagai metode ekstraksi ciri, yaitu Local Binary Patern (Achsani, 2015), Gabor Wavelet Transform (Praja, 2015) dan ekstraksi ciri statistik orde satu (Mahendra, et al, 2015) dengan metode klasifikasi yang sama yaitu k-NN. Diperoleh tingkat akurasi $89,4 \%$ pada Local Binary Patern, 75,6\% pada Gabor Wavelet Transform, dan 79,323\% pada ekstraksi ciri statistik. Pada penelitian (Jabo, 2011), SUSAN Edge detector cukup tahan terhadap noise dalam mendeteksi cacat retak pada kayu. Mengacu pada penelitian tersebut, peneliti membuat sistem deteksi adanya cacat pada kayu menggunakan citra HSV, deteksi tepi SUSAN, ekstraksi ciri statistik, dan metode klasifikasi k-Nearest Neighbour yang dibagi menjadi dua kelas yaitu: kayu normal (tanpa cacat) dan kayu rusak (cacat dengan cacat mata kayu atau cacat berupa retakan pada kayu). Rumusan masalah yang akan dihadapi sistem antara lain adalah: menganalisis performansi sistem berdasarkan hasil akurasi dari pemilihan citra berwarna transformasi citra RGB ke citra HSV, merancang sistem deteksi cacat kayu menggunakan metode deteksi tepi SUSAN dan ekstraksi ciri statistik, serta menentukan parameter dari metode yang memberikan akurasi terbaik.

\subsection{Transformasi Citra Berwana RGB ke Citra Berwarna HSV}

HSV (hue, saturation, value) merupakan ruang warna yang komponen-komponennya berkontribusi langsung pada persepsi visual manusia. Hue digunakan untuk membedakan warna merah, hijau, biru, dan untuk menentukan tingkat kemerahan, kehijauan, dst dari sebuah cahaya. Saturation merupakan persentase cahaya putih yang ditambahkan ke cahaya murni. Value merupakan intensitas cahaya yang dirasakan (Rodrigues, 2004).

Formula yang digunakan untuk transformasi RGB menjadi HSV, sebagai berikut:

$$
\begin{gathered}
h=\left\{\begin{array}{c}
\theta ; g \geq b \\
2 \pi-\theta ; g<b^{\prime}
\end{array}\right. \\
\theta=\cos ^{-1}\left[\frac{\frac{1}{2}[(r-g)+(r-b)]}{\sqrt{(r-g)^{2}+(r-b)(g-b)}}\right], \\
s=1-\frac{3}{r+g+b}[\min (r, g, b)],
\end{gathered}
$$




$$
v=\frac{1}{3}(r+g+b),
$$

dengan ( $r$, g, b) adalah warna-warna pada ruang warna RGB, dan ( $h, s, v)$ adalah warnawarna pada ruang warna HSV (Gonzales, 2004).

\subsection{SUSAN (Smallest Univalue Segment Assimilating Nucleus)}

SUSAN adalah algoritma yang dapat digunakan untuk melakukan deteksi fitur suatu objek dalam suatu citra. SUSAN menggunakan circular mask untuk mendeteksi tepi (edge) dan pojok (corner) dari suatu objek. Algoritma ini membandingkan nilai kecerahan setiap piksel yang terdapat di dalam mask dengan nilai piksel di tengah mask. Piksel di titik tengah tersebut disebut nucleus. Jumlah piksel yang memiliki nilai sama dengan nucleus dalam suatu mask didefinisikan sebagai Univalue Segment Assimilating Nucleus (USAN) area. Pendeteksian tepi atau pojok dari suatu objek merupakan pencarian daerah dengan nilai USAN area terkecil (Smith, 1997)

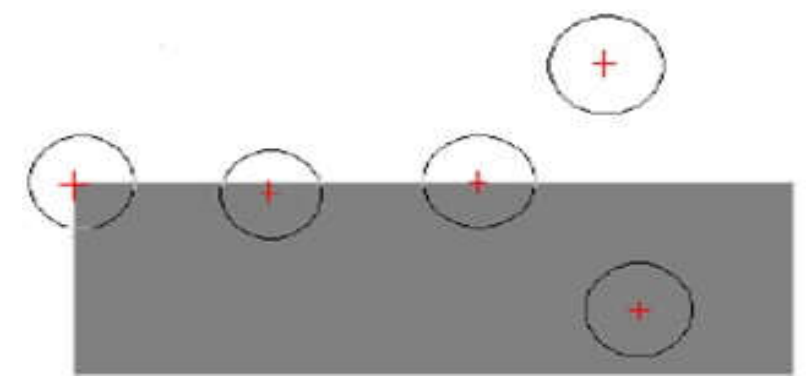

Gambar 1. Circular Mask algoritma SUSAN (Smith, 1997)

\subsubsection{SUSAN Edge Detection}

Deteksi tepi suatu objek menggunakan SUSAN memanfaatkan suatu circular mask. Mask ditempatkan di setiap titik dalam citra kemudian dibandingkan nilainya dengan titik tengah mask. Persamaan yang digunakan untuk pembandingan ini adalah (Smith, 1997):

$$
c\left(\bar{r}, \overline{r_{0}}\right)=\left\{\begin{array}{l}
1, j i k a\left|I(\bar{r})-I\left(\overline{r_{0}}\right)\right| \leq t \\
0, j i k a\left|I(\bar{r})-I\left(\overline{r_{0}}\right)\right|>t
\end{array},\right.
$$

dimana $\mathrm{r}_{0}$ adalah posisi nucleus dalam citra, $\mathrm{r}$ adalah posisi nucleus pada citra lain di dalam mask, I adalah nilai kecerahan piksel, t merupakan nilai threshold beda kecerahan, dan c merupakan hasil perbandingan.

Pembandingan dilakukan untuk setiap piksel di dalam mask dan kemudian dihitung nilai total hasil perbandingannya dengan persamaan :

$$
n\left(\overline{r_{0}}\right)=\sum_{r} c\left(\bar{r}, \overline{r_{0}}\right),
$$

dimana $\mathrm{n}$ merupakan jumlah total piksel SUSAN. Kemudan nilai $\mathrm{n}$ dibandingkan dengan nilai threshold g, yang disebut geometric threshold. Nilai g ditetapkan sebagai $3 \mathrm{nmax} / 4$. Initial edge response dihitung dengan menggunakan aturan sebagai berikut :

$$
R\left(\overline{r_{0}}\right)=\left\{\begin{array}{cl}
g-n\left(\overline{r_{0}}\right), & \text { jika } n\left(\overline{r_{0}}\right)<g, \\
0, & \text { lainnya }
\end{array},\right.
$$


dimana $R\left(\overline{r_{0}}\right)$ merupakan hasil garis tepi (edge response). Dari persamaan tersebut terlihat bahwa semakin kecil daerah SUSAN maka semakin besar edge response. Persamaan yang digunakan SUSAN untuk menghitung jumlah piksel yang memiliki derajat kecerahan yang mirip dengan nucleus (Novamizanti, 2011).

\subsubsection{SUSAN Corner Detection}

Prinsip kerja SUSAN corner detection hampir sama dengan edge detection yaitu dengan membandingkan semua piksel di dalam mask dengan nucleus(Anna, 2011). Persamaan yang digunakan SUSAN untuk menghitung jumlah piksel yang memiliki derajat kecerahan yang mirip dengan nucleus adalah :

$$
N\left(\overline{r_{0}}\right)=\sum_{r C R}\left\{1-\delta\left(|| I(\bar{r})-I\left(\overline{r_{0}}\right) \|-t\right)\right\},
$$

dimana $\mathrm{N}\left(\overline{r_{0}}\right)$ adalah jumlah piksel, $\mathrm{I}\left(\overline{r_{0}}\right)$ adalah kecerahan nucleus, $\mathrm{I}(\bar{r})$ adalah kecerahan piksel dalam circular mask, $\mathrm{R}$ adalah radius mask, dan t adalah threshold. $\delta(x)$ dihitung sebagai berikut:

$$
\delta(x)\left\{\begin{array}{l}
1, x>0 \\
0, x \leq 0
\end{array}\right.
$$

Nucleus akan menjadi corner saat $\mathrm{N}\left(r_{0}\right)$ menjadi nilai 1430cal minimum (Wu, et al, 2001).

\subsection{Ekstraksi Ciri Statistik}

Ekstraksi ciri statistik dibagi menjadi dua, yaitu : ektraksi ciri statistik orde pertama dan ekstraksi ciri statistik orde kedua.

\subsubsection{Ekstraksi Ciri Statistik Orde Pertama}

Ekstraksi ciri orde pertama merupakan metode pengambilan ciri yang didasarkan pada karakteristik histogram citra. Histogram menunjukkan probabilitas kemunculan nilai derajat keabuan piksel pada suatu citra. Dari nilai-nilai pada histogram yang dihasilkan, dapat dihitung beberapa parameter ciri orde pertama, antara lain adalah mean, skewness, variance, kurtosis, dan entropy (Modul Praktikum Pengolahan Citra, 2008).

a. Mean $(\mu)$, menunjukkan ukuran dispersi dari suatu citra.

$$
\mu=\sum_{n} f_{n} p\left(f_{n}\right),
$$

Dimana $f_{n}$ merupakan suatu nilai intensitas keabuan, sementara $p\left(f_{n}\right)$ menunjukkan nilai histogramnya (probabilitas kemunculan intensitas tersebut pada citra).

b. Variance $\left(\sigma^{2}\right)$, menunjukkan variasi elemen pada histogram dari suatu citra.

$$
\sigma^{2}=\sum_{n}\left(f_{n}-\mu\right)^{2} p\left(f_{n}\right) .
$$

c. Skewness $\left(\mathrm{a}_{3}\right)$, menunjukkan tingkat kemencengan relatif kurva histogram dari suatu citra.

$$
\alpha_{3}=\frac{1}{\alpha_{3}} \sum_{n}\left(f_{n}-\mu\right)^{3} p\left(f_{n}\right) .
$$

d. Kurtosis $\left(\mathrm{a}_{4}\right)$, menunjukkan tingkat keruncingan relatif kurva histogram dari suatu citra.

$$
\alpha_{4}=\frac{1}{\alpha_{4}} \sum_{n}\left(f_{n}-\mu\right)^{4} p\left(f_{n}\right)-3 .
$$


e. Entropy $(H)$, menunjukkan ukuran ketidakteraturan bentuk dari suatu citra.

$$
H=-\sum_{n} p\left(f_{n}\right)^{2} \log p\left(f_{n}\right) .
$$

\subsubsection{Ekstraksi Ciri Statistik Orde Kedua}

Pada beberapa kasus, ciri orde pertama tidak lagi dapat digunakan untuk mengenali perbedaan antar citra. Pada kasus seperti ini, kita membutuhkan pengambilan ciri statistik orde dua. Salah satu teknik untuk memperoleh ciri statistik orde dua adalah dengan menghitung probabilitas hubungan ketetanggaan antara dua piksel pada jarak dan orientasi sudut tertentu. Pendekatan ini bekerja dengan membentuk sebuah matriks kookurensi dari data citra, dilanjutkan dengan menentukan ciri sebagai fungsi dari matriks antara tersebut (Novamizanti, 2015).

Kookurensi berarti kejadian bersama, yaitu jumlah kejadian satu level nilai piksel bertetangga dengan satu level nilai piksel lain dalam jarak ( $d$ ) dan orientasi sudut $(\theta)$ tertentu. Jarak dinyatakan dalam piksel dan orientasi dinyatakan dalam derajat. Orientasi dibentuk dalam empat arah sudut dengan interval sudut $45^{\circ}$, yaitu $0^{\circ}, 45^{\circ}, 90^{\circ}$, dan $135^{\circ}$. Sedangkan jarak antar piksel biasanya ditetapkan sebesar 1 piksel. Parameter - parameter yang akan dihitung pada ektrasi ciri statistik orde kedua ini adalah Angular Second Moment, Contrast, Correlation, Variance, Inverse Difference Moment, dan Entropy (Modul Praktikum Pengolahan Citra, 2008).

a. Angular Second Moment, menunjukkan ukuran sifat homogenitas citra.

$$
A S M=\sum_{i} \sum_{j}\{p(i, j)\}^{2},
$$

Dimana $p(i, j)$ menyatakan nilai pada baris i dan kolom j pada matriks kookurensi.

b. Contrast, menunjukkan ukuran penyebaran (momen inersia) elemen-elemen matriks citra. Jika letaknya jauh dari diagonal utama, nilai kekontrasan besar. Secara visual, nilai kekontrasan adalah ukuran variasi antar derajat keabuan suatu daerah citra.

$$
\begin{gathered}
\operatorname{CON}=\sum_{k} k^{2}\left[\sum_{i} \sum_{j} p(i, j)\right] \\
{[i-j]=k}
\end{gathered}
$$

c. Correlation, menunjukkan ukuran ketergantungan linear derajat keabuan citra sehingga dapat memberikan petunjuk adanya struktur linear dalam citra.

$$
C O R=\frac{\sum_{i} \sum_{j}(i j) \cdot p(i, j)-\mu_{x} \mu_{y}}{\sigma_{x} \sigma_{y}}
$$

d. Variance, menunjukkan variasi elemen-elemen matriks kookurensi. Citra dengan transisi derajat keabuan kecil akan memiliki variansi yang kecil pula.

$$
V A R=\sum_{i} \sum_{j}\left(i-\mu_{x}\right)\left(j-\mu_{y}\right) p(i, j) .
$$

e. Inverse Different Moment, menunjukkan kehomogenan citra yang berderajat keabuan sejenis. Citra homogen akan memiliki harga IDMyang besar.

$$
I D M=\sum_{i} \sum_{j} \frac{1}{1+(i-j)^{2}} p(i, j) .
$$


f. Entropy, menunjukkan ukuran ketidakteraturan bentuk. Harga ENT besar untuk citra dengan transisi derajat keabuan merata dan bernilai kecil jika struktur citra tidak teratur (bervariasi).

$$
E N T_{2}=-\sum_{i} \sum_{j} p(i, j) .^{2} \log p(i, j)
$$

\section{$1.4 k$-Nearest Neighbour (k-NN)}

Prinsip kerja $k$-Nearest Neighbor (k-NN) adalah mencari jarak terdekat antara data yang akan dievaluasi dengan k tetangga (neighbor) terdekatnya dalam data pelatihan. Mirip dengan teknik klastering, mengelompokkan suatu data baru berdasarkan jarak data baru itu ke beberapa data/tetangga (neighbor) terdekat. Nilai k yang terbaik untuk algoritma ini tergantung pada data. Secara umum, nilai k yang tinggi akan mengurangi efek noise pada klasifikasi, tetapi membuat batasan antar setiap klasifikasi semakin kabur. Metode jarak yang akan digunakan pada penelitian ini adalah Euclidean Distance (Prasetyo, 2012).

Euclidean Distance adalah metrika yang paling sering digunakan untuk menghitung kesamaan dua vektor. Euclidean Distance menghitung akar dari kuadrat perbedaan dua vektor. Rumus Euclidean Distance:

$$
d_{i}=\sqrt{\sum_{i=1}^{p}\left(x_{2 i}-x_{1 i}\right)^{2}}
$$

dimana $X_{1}=$ sampel data, $X_{2}=$ data uji/testing,$i=$ variabel data, $d=$ jarak, $p=$ dimensi data

\subsection{Kerusakan dan Cacat Pada Kayu}

Kerusakan pada kayu adalah menurunnya kekuatan kayu akibat adanya/terjadinya retakretak, pecah-pecah, belah, pelapukan karena cuaca, serangan serangga atau jamur; juga menurunnya mutu kayu akibat terjadinya perubahan warna, berubahnya nilai dekoratif. Hal ini dapat diakibatkan oleh ulah manusia yang kurang cermat dalam mengelola kayu (Modul Teknologi Bahan Kayu, 2015), misalnya:

a. Pemeliharaan hutan yang kurang baik,

b. Cara penebangan pohon yang salah,

c. Pembagian kayu yang keliru,

d. Cara menggergaji yang keliru, dan

e. Pengeringan kayu yang tidak sesuai.

Hal yang akan dibahas pada penelitian ini adalah pendeteksian pada cacat mata kayu dan cacat berupa retakan pada kayu yang akan digunakan dalam pensortiran kayu olahan untuk mengurangi adanya human error.

Mata kayu merupakan lembaga atau bagian cabang yang berada di dalam kayu. Mata kayu dapat dibedakan :

a. Mata kayu sehat, yaitu mata kayu yang tidak busuk, berpenampang keras, tumbuh kukuh dan rapat pada kayu, berwarna sama atau lebih gelap dibandingkan dengan kayu sekitarnya.

b. Mata kayu lepas, yaitu mata kayu yang tidak tumbuh rapat pada kayu, biasanya pada proses pengerjaan, mata kayu ini akan lepas dan tidak ada gejala busuk.

c. Mata kayu busuk, yaitu mata kayu yang menunjukkan tanda-tanda pembusukan dan bagian-bagian kayunya lunak atau lapuk, berlainan dengan bagian-bagian kayu sekitarnya. 
Pengaruh mata kayu :

a. Mengurangi sifat keteguhan kayu.

b. Menyulitkan pengerjaan karena kerasnya penampang mata kayu (mata kayu sehat).

c. Mengurangi keindahan permukaan kayu.

d. Menyebabkan lubangnya lembaran-lembaran finir.

Pada kayu bulat sering terlihat adanya serat-serat yang terpisah memanjang. Berdasarkan ketentuan pengujian kayu, maka :

a. Jika lebar terpisahnya serat $\leq 2 \mathrm{~mm}$, dinamakan retak.

b. Lebar terpisahnya serat $\leq 6 \mathrm{~mm}$, dinamakan pecah.

c. Lebar terpisahnya serat $\geq 6 \mathrm{~mm}$, dinamakan belah.

Pada penelitian ini, sistem yang akan dibuat tidak akan membedakan apakah itu retak, pecah, ataupun belah. Karena cacat retakpun sudah temasuk cacat yang akan mempengaruhi kekuatan kayu dan umur dari hasil olahan kayu tersebut. Penyebab terjadinya cacat pecah dan belah, diantaranya :

a. Ketidakseimbangan arah penyusutan pada waktu kayu menjadi kering.

b. Tekanan di dalam tubuh kayu yang kemudian terlepas pada waktu kayu ditebang.

c. Kesalahan dalam teknik penebangan atau menimpa benda-benda keras.

Pengaruh cacat pecah atau belah :

a. Mengurangi keteguhan tarik.

b. Mengurangi keteguhan kompresi, distribusi beban jadi tidak merata.

c. Keteguhan geser berkurang, akibat luasan daerah yang menahan beban berkurang.

\section{METODOLOGI PENELITIAN}

Tujuan dari penelitian ini adalah merancang sebuah sistem pendeteksian kayu dengan kondisi normal (tanpa cacat) dan rusak (cacat dengan cacat mata kayu atau cacat berupa retakan pada kayu) dengan metode deteksi tepi SUSAN (Smallest Univalue Segment Assimilating Nucleus) Edge Detector dan ekstraksi ciri statistik, sehingga berguna dalam penyortiran kayu untuk mengurangi adanya human error dan tahap penyortiran akan menjadi lebih efektif.

Langkah-langkah metodologi penelitian yang dilakukan untuk mencapai tujuan tersebut, adalah sebagai berikut :

1. Pencarian referensi melalui studi pustaka tentang:

a. Kayu.

b. Pengolahan citra digital dan transformasi citra RGB ke citra HSV.

c. Deteksi tepi SUSAN

d. Algoritma k-NN

2. Pengumpulan Data

Bertujuan untuk mendapatkan data citra kayu yang akan menjadi input dalam sistem. 


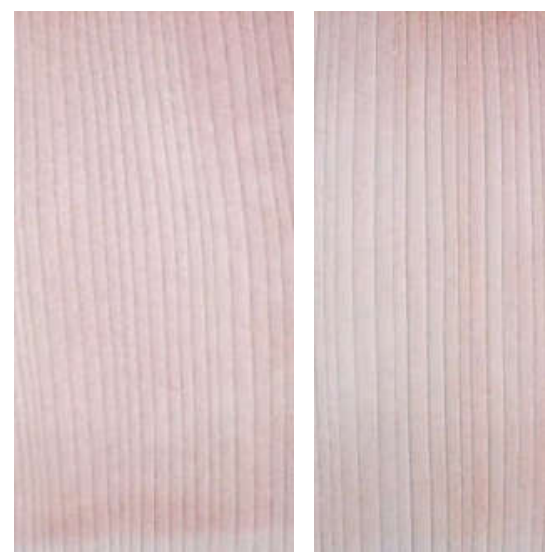

(a)

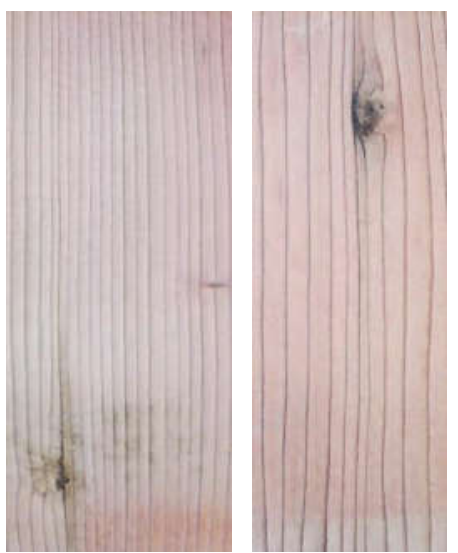

(b)

Gambar 2. Contoh Citra Kayu (a) Kayu Normal, (b) Kayu Cacat

Data diperoleh dari industri kayu yang ada di Bandung. Total citra kayu yang digunakan dalam penelitian sebanyak 350 citra. Pada proses pelatihan menggunakan 50 citra yang dibagi menjadi 25 citra kayu normal (tanpa cacat) dan 25 citra kayu rusak (cacat dengan cacat mata kayu atau cacat berupa retakan pada kayu), sedangkan pada proses pengujian menggunakan citra sebanyak 300 buah citra yang dibagi menjadi 150 citra kayu normal (tanpa cacat) dan 150 citra kayu rusak (cacat dengan cacat mata kayu atau cacat berupa retakan pada kayu).

3. Perancangan Sistem

Secara umum sistem dibagi menjadi lima tahap. Pertama, pengambilan citra kayu akan dilakukan secara offline dengan kamera digital, dimana format citra yang dihasilkan berupa citra RGB. Input citra RGB di tranformasi ke citra HSV dan dibagi per/ayer sebagai pembanding akurasi sistem. Selanjutnya dilakukan proses deteksi tepi dengan metode SUSAN, sehingga menghasilkan citra biner. Citra biner hasil deteksi tepi SUSAN tersebut diproses kembali menggunakan metode ekstraksi ciri statistik, yang selanjutnya akan diklasifikasikan dengan metode k-Nearest Neighbour dalam dua class, yaitu : kayu normal (tanpa cacat) dan kayu rusak (cacat dengan cacat mata kayu atau cacat berupa retakan pada kayu). Setelah itu akan didapatkan output berupa hasil deteksi apakah kayu tersebut kayu normal atau kayu rusak.

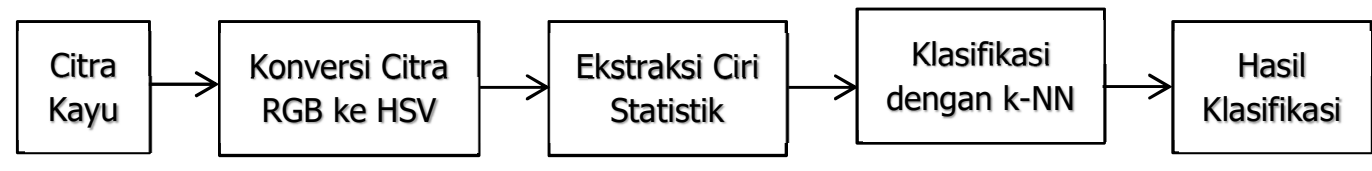

\section{Gambar 3. Gambaran Umum Sistem Deteksi Kayu}

4. Implementasi Perangkat Lunak

Sistem dirancang dengan menggunakan Matlab R2015a.

5. Analisis Performansi

Melakukan analisis performansi pendeteksian kayu dengan kondisi normal (tanpa cacat) dan rusak (cacat dengan cacat mata kayu atau cacat berupa retakan pada kayu) menggunakan metode deteksi tepi SUSAN dan ekstraksi ciri statistik. Parameter performansi sistem yang digunakan, yaitu tingkat akurasi. 
6. Pembandingan Metode

Membandingan parameter yang ada pada metode deteksi tepi SUSAN, dan metode ciri statistik orde statistik mana yang paling baik untuk mendapatkan ciri sebuah kayu.

7. Pengambilan Kesimpulan

Mengambil kesimpulan setelah melakukan pengujian sistem pendeteksian kayu menggunakan metode deteksi tepi SUSAN, dan ekstraksi ciri statistik.

\section{HASIL DAN DISKUSI}

Sebelum melakukan skema pengujian pada sistem yang telah dirancang, perlu adanya proses pelatihan pada 50 buah data citra latih. Proses pelatihan ini akan menggunakan beberapa parameter uji, yaitu nilai threshold $(\mathrm{t}=0.01,0.05,0.1,0.2$, dan 0.3$)$, mask size (mask size = 3,5 , dan 7), ekstraksi ciri statistik orde pertama dan orde kedua, $\mathrm{k}=1$ dan metode jarak Euclidean Distance.

Tabel 1. Hasil Pelatihan Nilai Threshold (t) pada Deteksi Tepi SUSAN

\begin{tabular}{|l|c|c|c|c|c|}
\hline \multicolumn{6}{|c|}{ Mask Size = 3; Ekstraksi Ciri = Orde 1 dan 2; k = 1 Euclidean Distance } \\
\hline \multirow{2}{*}{ Layer } & 0,01 & 0,05 & 0,1 & 0,2 & 0,3 \\
\cline { 2 - 6 } & $100 \%$ & $100 \%$ & $98 \%$ & $98 \%$ & $98 \%$ \\
\hline Hue & $100 \%$ & $100 \%$ & $100 \%$ & $88 \%$ & $82 \%$ \\
\hline Saturation & $100 \%$ & $100 \%$ & $100 \%$ & $98 \%$ & $96 \%$ \\
\hline Value &
\end{tabular}

Berdasarkan Tabel 1, pengujian nilai threshold $(\mathrm{t})=0,01 ; 0,05$ dan 0,1 pada ketiga layer menghasilkan tingkat akurasi sebesar $100 \%$ pada nilai $t<0,1$ dan layer hue. Semakin besar nilai t maka jumlah piksel yang memiliki derajat kecerahan yang mirip dengan nucleus akan makin berkurang. Sehingga hasil edge response menjadi tidak optimal.

Tabel 2. Hasil Pelatihan Mask Size pada Deteksi tepi SUSAN

\begin{tabular}{|c|c|c|c|c|c|c|c|c|}
\hline \multicolumn{7}{|c|}{ Ekstraksi Ciri = Orde 1 dan 2; k = 1 Euclidean Distance } \\
\hline \multirow{3}{*}{ Mask Size } & \multicolumn{7}{|c|}{ Nilai t } & \multicolumn{2}{c|}{} \\
\cline { 2 - 9 } & 0,01 & 0,05 & 0,01 & 0,05 & 0,1 & 0,01 & 0,05 & 0,1 \\
\cline { 2 - 9 } & \multicolumn{3}{|c|}{ Hue } & \multicolumn{3}{|c|}{ Saturation } & \multicolumn{3}{c|}{ Value } \\
\hline 3 & $100 \%$ & $100 \%$ & $100 \%$ & $100 \%$ & $100 \%$ & $100 \%$ & $100 \%$ & $100 \%$ \\
\hline 5 & $100 \%$ & $100 \%$ & $100 \%$ & $100 \%$ & $100 \%$ & $100 \%$ & $100 \%$ & $100 \%$ \\
\hline 7 & $100 \%$ & $100 \%$ & $100 \%$ & $100 \%$ & $100 \%$ & $100 \%$ & $100 \%$ & $100 \%$ \\
\hline
\end{tabular}

Berdasarkan Tabel 2, saat proses pelatihan terhadap mask size $=3$, 5, dan 7 dengan parameter terbaik pada Tabel 1, menunjukkan bahwa semua mask size dapat menghasilkan tingkat akurasi sebesar $100 \%$. Artinya parameter mask size tidak berpengaruh terhadap sistem, karena semua nilai mask yang ada pada USAN area akan meliputi keseluruhan struktur dari sebuah citra pada setiap area yang telah dipetakan.

\subsection{Hasil Pengujian}

Berikut merupakan hasil pengujian terhadap 300 buah citra uji dalam peroses pengujian terhadap nilai threshold $(\mathrm{t})$ dan mask size. 


\subsubsection{Proses Pengujian Pada Citra HSV dan Deteksi Tepi SUSAN}

Pada pengujian ini, digunakan beberapa parameter uji, yaitu layer citra HSV (Hue, Saturation, dan Value) nilai threshold ( $\mathrm{t}=0,01 \mathrm{s.d} 0,1)$, mask size (mask size $=3 ; 5$; dan 7), ekstraksi ciri statistik orde pertama dan orde kedua, $\mathrm{k}=1$ dan metode jarak Euclidean Distance.

Tabel 3. Hasil Pengujian Citra HSV pada Nilai t dan Mask Size

\begin{tabular}{|c|c|c|c|c|c|c|c|c|}
\hline \multicolumn{8}{|c|}{ Ekstraksi Ciri = Orde 1 dan 2; k = 1 Euclidean } \\
\hline \multirow{2}{*}{$\begin{array}{c}\text { Mask } \\
\text { Size }\end{array}$} & \multicolumn{9}{|c|}{ Nilai t } \\
\cline { 2 - 10 } & 0,01 & 0,05 & 0,01 & 0,05 & 0,1 & 0,01 & 0,05 & 0,1 \\
\hline \multirow{2}{|c|}{ Hue } & \multicolumn{3}{c|}{ Saturation } & \multicolumn{3}{c|}{ Value } \\
\hline 3 & $58,00 \%$ & $66,00 \%$ & $64,67 \%$ & $83,00 \%$ & $90,33 \%$ & $53,00 \%$ & $57,00 \%$ & $57,00 \%$ \\
\hline 5 & $57,66 \%$ & $61,67 \%$ & $57,33 \%$ & $74,67 \%$ & $89,00 \%$ & $46,67 \%$ & $54,67 \%$ & $57,67 \%$ \\
\hline 7 & $64,33 \%$ & $62,00 \%$ & $58,67 \%$ & $70,67 \%$ & $88,67 \%$ & $51,00 \%$ & $56,67 \%$ & $59,67 \%$ \\
\hline
\end{tabular}

Berdasarkan Tabel 3, secara umum layer Saturation menghasilkan performasi lebih baik daripada layer lainnya. Hal ini karena Saturation merupakan persentase cahaya putih yang ditambahkan ke cahaya murni. Hal ini sesuai dengan penentuan area USAN yang direpresentasikan pada bagian putih dari mask. Tingkat akurasi tertinggi terdapat pada layer saturation, $\mathrm{t}=0,1$ dan mask size $=3$ sebesar 90,33\%. Paremeter ini akan diujikan lagi untuk menentukan ciri dari ekstraksi ciri statistik orde pertama dan orde kedua yang mempunyai tingkat akurasi tertinggi.

\subsubsection{Analisis Pengaruh tiap Ciri dari Ekstraksi Ciri Statistik terhadap Akurasi Sistem}

Ekstraksi ciri statistik dibagi menjadi dua, yaitu : ekstraksi ciri statistik orde pertama dan ekstraksi ciri statistik orde kedua. Ekstraksi ciri statistik orde pertama mempunyai 5 parameter histogram citra, antara lain adalah mean, skewness, variance, kurtosis, dan entropy. Sedangkan ekstraksi ciri statistik orde kedua mempunyai 6 parameter hubungan probabilitas ketetanggaan, antara lain adalah angular second moment(ASM), contrast, correlation, inverse different moment (IDM), variance, dan entropy. Proses pengujian ini akan menggunakan parameter hasil pengujian dengan tingkat akurasi tertinggi sebelumnya, yaitu :

1. Layer Saturation pada citra HSV.

2. Nilai threshold, $\mathrm{t}=0,1$ pada metode SUSAN Edge Detector.

3. Mask Size $=3$ pada metode SUSAN Edge Detector.

4. Nilai $\mathrm{k}=1$ pada metode klasifikasi k-Nearest Neighbour dengan jarak distance euclidean.

Berdasarkan hasil pengujian terhadap tiap ciri pada ekstraksi ciri statistik, grafik pada Gambar 4 menunjukkan bahwa secara umum hasil ekstraksi ciri dengan statistik orde kedua lebih baik dari pada orde satu. Perhitungan probabilitas hubungan ketetanggaan antara dua piksel pada jarak dan orientasi sudut pada posisi corner SUSAN mengakibatkan ciri dari tiap kayu semakin detail. Sifat homogenitas atau derajat keabuan yang sama antar pikselnya dan kookurensi yang berarti kejadian bersama satu level nilai piksel bertetangga dengan satu level nilai piksel lainnya. Pada ciri statistik orde kedua, akurasi tertinggi sebesar $90,67 \%$ terdapat pada metode ciri angular second moment(ASM), correlation, variance, dan inverse different moment (IDM). Keempat ciri tersebut pada prinsipnya sama, yaitu menunjukkan sifat homogenitas atau derajat keabuan yang sama antar pikselnya dan kookurensi yang berarti kejadian bersama satu level nilai piksel bertetangga dengan satu level nilai piksel lainnya. 


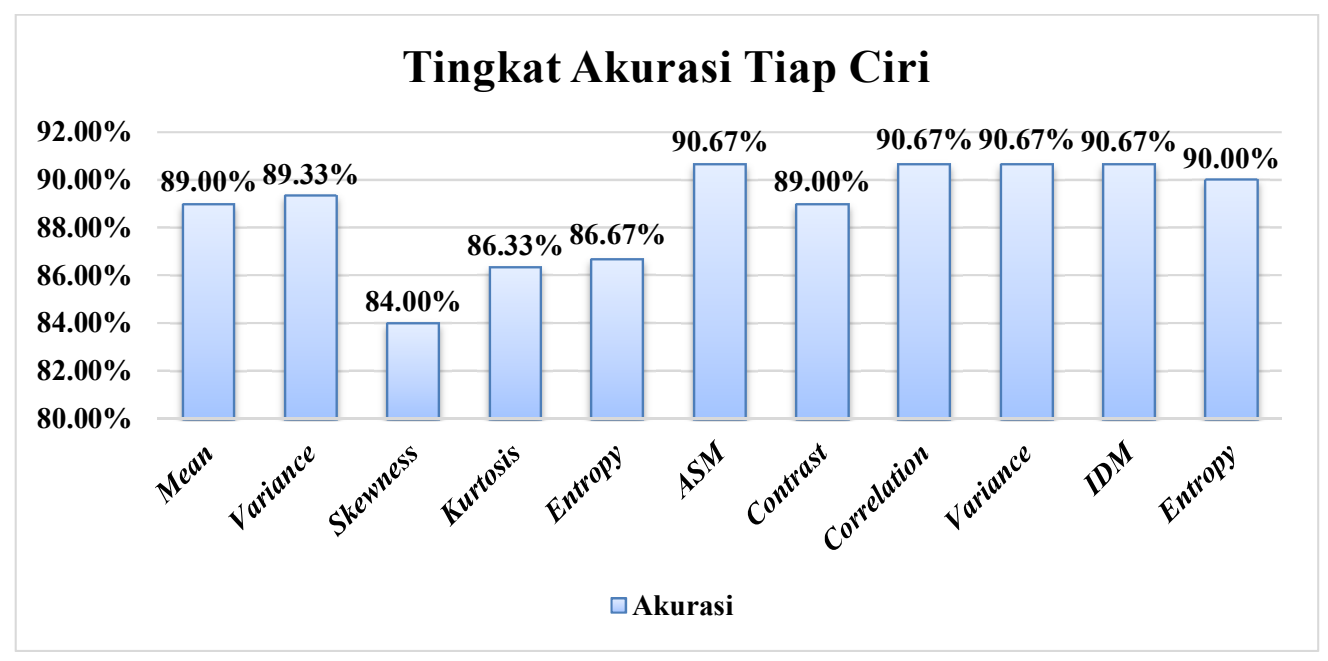

Gambar 4. Hasil Pengujian Tiap Ciri

Pada proses pengujian selanjutnya akan dilakukan pengujian dengan metode klasifikasi kNearest Neighbour pada nilai k yang dapat menghasilkan tingkat akurasi tertinggi.

\subsubsection{Analisis Pengaruh Parameter k pada Metode k-Nearest Neighbour terhadap Akurasi Sistem}

Metode k-Nearest Neighbour ini digunakan untuk mengklasifikasikan citra kayu menjadi dua class, yaitu : kayu normal (tanpa cacat) dan kayu rusak (cacat berupa cacat mata kayu maupun cacat berupa retakan pada kayu). Pada proses pengujian ini akan menggunakan variabel tetap dan variabel berubah. Variabel tetap yang digunakan adalah parameter tingkat akurasi data tertinggi pada proses pengujian sebelumnya, yaitu :

1. Layer yang digunakan adalah layer saturation pada citra HSV.

2. Nilai t pada metode SUSAN Edge Detector adalah $\mathrm{t}=0,1$.

3. Mask Size pada metode SUSAN Edge Detector yang digunakan adalah 3.

4. Ekstraksi ciri statistik orde kedua dengan parameter ciri, antara lain adalah : angular second moment (ASM), correlation, variance, dan inverse different moment (IDM).

Sedangkan variabel yang berubah, yaitu $\mathrm{k}=1$; 3; dan 5 dengan metode jarak Euclidean Distance.

Hasil pengujian parameter $\mathrm{k}$ terhadap akurasi yang menghasilkan grafik pada Gambar 5. Akurasi tertinggi, sebesar 90,67\% diperoleh saat nilai $\mathrm{k}=1$, untuk ciri angular second moment (ASM), correlation, variance, dan inverse different moment (IDM) pada ekstraksi ciri statistik orde kedua. Dari pengujian tersebut, diperoleh bahwa semakin besar nilai k maka tingkat akurasi akan semakin berkurang, dan semakin membuat batasan antar setiap klasifikasi semakin kabur. 


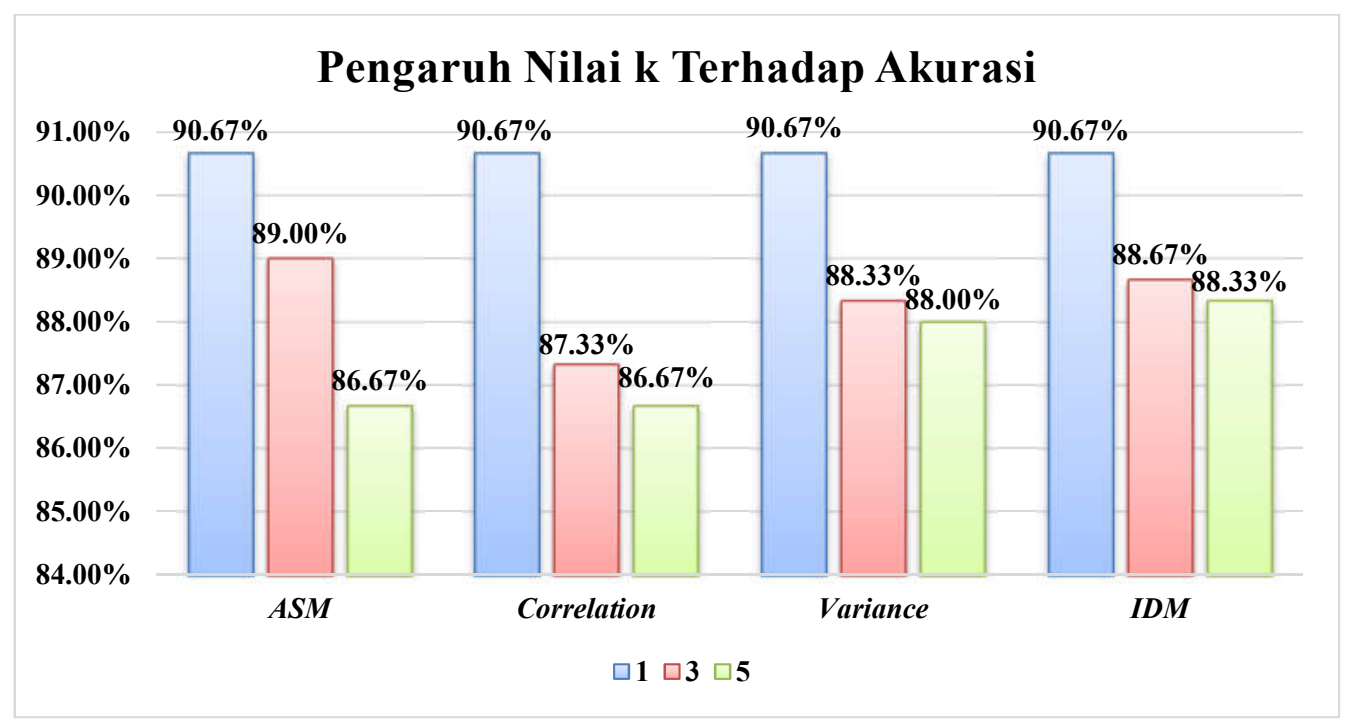

Gambar 5. Hasil Pengujian Parameter k pada Metode k-Nearest Neighbour

\section{KESIMPULAN}

Pada penelitian ini telah dirancang sebuah sistem pendeteksian kayu dengan kondisi normal (tanpa cacat) dan rusak (cacat dengan cacat mata kayu atau cacat berupa retakan pada kayu) dengan metode SUSAN Edge Detector dan ekstraksi ciri statistik orde kedua, dengan tingkat akurasi sebesar $90,67 \%$ dan waktu komputasi 2,5 detik. Berdasarkan implementasi dan hasil pengujian pada sistem, diperoleh kesimpulan sebagai berikut:

1. Metode SUSAN Edge Detector dapat mendeteksi cacat pada kayu dengan parameter nilai threshold $(\mathrm{t})=0,1$; mask size $=3$.

a. Semakin besar nilai t maka jumlah piksel yang memiliki derajat kecerahan yang mirip dengan nucleus akan makin berkurang. Sehingga hasil edge responsemenjadi tidak optimal.

b. Parameter mask size tidak berpengaruh terhadap sistem, karena semua mask yang ada pada USAN area akan meliputi keseluruhan struktur dari sebuah citra kayu pada setiap area yang telah dipetakan.

2. Metode ekstraksi ciri statistik orde kedua pada ciri angular second moment (ASM), correlation, variance, dan inverse different moment (IDM) menunjukkan sifat homogenitas atau derajat keabuan yang sama antar pikselnya dan kookurensi yang berarti kejadian bersama satu level nilai piksel bertetangga dengan satu level nilai piksel lainnya.

3. Pada klasifikasi k-NN menggunakan nilai $\mathrm{k}=1$ dan jarak Euclidean Distance. Semakin tinggi nilai k maka akan semakin membuat batasan antar setiap klasifikasi kayu semakin kabur

\section{DAFTAR RUJUKAN}

Achsani, F. (2015). Deteksi Adanya Cacat Pada Kayu Menggunakan Metode Local Binary Patern. Bandung: Telkom University.

Anna, A. and Rizal, A. and Novamizanti, L. (2011). Analisis Deteksi Wajah Menggunakan Deteksi Tepi. Bandung: Telkom University. 
Novamizanti, L., Kurnia, A. (2015). Analisis Perbandingan Kompresi Haar Wavelet Transform dengan Embedded Zerotree Wavelet pada Citra. Elkomika, 3 (2), 161-176.

Survey Badan Pusat Statistik. (2017). [online] Arab Saudi, Pasar Ekspor Kayu Lapis Terbesar Ketiga Indonesia. Diakses pada tanggal 10 Oktober 2017 dari http://databoks.katadata.co.id/datapublish/2017/03/03/saudi-pasar-ekspor-kayu-lapisterbesar-ketiga-indonesia?_ga=2.228940508.1356231837.1507523653740541824.1507523653.

Gonzales, R, Woods R. (2008). Digital Image Processing, Third Edition. Prentice Hall.

Jabo, S. (2011). Machine Vision for Wood Defect Detection and Classification. Sweden: Chalmers University of Technology.

Kadir, A., \& Susanto, A. (2013). Teori dan Aplikasi Pengolahan Citra. Yogyakarta: Andi.

Praja, MPK. (2015). Implementasi Sistem Pendeteksi Cacat Pada Kayu Menggunakan Metode Gabor Wavelet Transform. Bandung: Telkom University.

Prasetyo, E. (2012). Data Mining Konsep dan Aplikasi Menggunakan Matlab. Yogyakarta: Andi.

Mahendra, SB. and Novamizanti, L. and Atmaja, R.D. (2015). Deteksi Ada Tidaknya Cacat Pada Kayu Menggunakan Metode Ekstraksi Ciri Statistik. Bandung: Telkom University.

Smith, S., \& Brady, J. (1997). SUSAN - A New Approach To Low Level Image Processing. International Journal of Computer Vision.

WU, H., Junya, I., Shioyama, T., CHEN, Q., \& \& SIMADA, Y. (2001). Automatic Facial Feature Points Detection with SUSAN Operator. Proceedings of the Scandinavian Conference on Image Analysis, (pp. 257-263). 